\title{
An Examination of the Persistent Effects of Franchising Strategy on Large Chains
}

\author{
Vinay Kumar Garg \\ Department of Management, College of Business Administration \\ Missouri State University, 901 South National Avenue, Springfield, MO 65897, USA \\ Tel: 417-836-5581Ｅ-mail: vinaygarg@missouristate.edu
}

Received: November 8, 2018 Accepted: November 23, 2018 Published: December 22, 2018

doi:10.5296/ber.v9i1.14089

URL: https://doi.org/10.5296/ber.v9i1.14089

\begin{abstract}
In the US economy, retail chains are extremely important since they account for a very high share of GDP relative to manufacturing sector. Retail is dominated by large franchised chains, particularly in the restaurant industry. A proven business format comprising a differentiated menu, exterior and interior design of the outlet, logos, etc., draws the interest of many prospective franchisees simultaneously, especially to large chains because it reduces their risk. Theoretical arguments are built, supported in relevant research, to present three hypotheses. Together, they form a theory of how franchising helps large chains despite abating of resource scarcity and escalation of threat from agency problems. Developing such a theory is important because extant research does not adequately address the boundary condition of large chains, even though many of them have been becoming from large to mega for many years. This theory is tested in a longitudinal sample from Quick Service Restaurant magazine, which has been publishing a list of top 50 restaurant chains for many years. All of three hypotheses are strongly supported. The paper closes with discussion of results and their implications for practice and research.
\end{abstract}

Keywords: Franchising, Restaurants, Strategy, Chains

\section{Introduction}

In the US economy, retail chains are extremely important; they were found to have a share of GDP about "three times that of the entire manufacturing sector (Gupta, Hoopes, \& Knott, 2015: 851-52)". Most chains have an increasing preference for franchising, even when they use plural forms of organization wherein the franchisor also owns outlets (Garg, Rasheed, \& Priem, 2005). Franchising is a form of cooperative entrepreneurship (Akremi, Mignonac, \& Perrigot, 2010), which has been gaining popularity in retail trade and services ever since 
legendary entrepreneurs such as Ray Kroc (for McDonald's), Jim McLamore (for Burger King), and Dave Thomas (for Wendy's) started using it to build fast food chains many decades ago (Kroc and Anderson, 1977; Thomas, 1994; McLamore, 1998). The prominence of franchising arose due to its compelling appeal to both franchisors, who developed unique business format and brand identity (Michael, 2009), and prospective franchisees who wanted to quickly start a business by tapping into a differentiated and successful brand (Garg, 2013) by paying an initial fee and royalty (Anderson, 1984).

A proven business format comprising a differentiated menu, exterior and interior design of the outlet, logos, etc., draws the interest of many prospective franchisees simultaneously. The franchisor finds franchising to be a rapid method of growth for her chain because franchisees bring a bundle of critical resources comprising financial capital, managerial talent, and local knowledge (Caves \& Murphy, 1977; Michael, 2003; Wu, 2015). A new franchisor would have difficulty in finding those crucial resources in sufficient quantities otherwise to deploy in many geographic markets simultaneously. This is the essence of the resource scarcity thesis of franchising. Several issues surround this thesis, however.

First, as the chain grows, the franchisor will have to deal with "agency problems associated with operating a network of decentralized production network (Michael, 1999: 313)." An unavoidable fact faced by decentralized production networks such as a large chain of fast food restaurants dependent on hundreds, even thousands of franchisees, is that the agent franchisee's goals may diverge from the principal franchisor's goals (Fama \& Jensen, 1983; Eisenhardt, 1989). Agency problems such as adverse selection and free riding can result when the goal divergence occurs (Dant \& Nasr, 1998). Some franchisees may misrepresent information regarding their skills (Shane, 1996) or withhold their effort fearing that other franchisees of the same system will not put in sufficient efforts to maintain the value of the franchised brand (Jensen \& Meckling, 1976). Inability of the franchisor to monitor those behaviors may drive the prospective franchisee to behave opportunistically (Eisenhardt, 1988). Even very carefully designed contracts may not prevent opportunistic behaviors of franchisees because large number of contracts are difficult to enforce (Cochet \& Garg, 2008). Franchisors more concerned about franchisee opportunism may therefore open more outlets under their ownership once resource scarcities abate as their chain grows large.

Second, a franchisor may also prefer to open company-owned outlets in new markets (Gallini \& Lutz, 1992) to signal to prospective franchisees that she is committed to providing quality and monitoring the behavior of other franchisees (Michael, 2000) and as sites for developing and trying out new ideas in heterogeneous markets (Garg \& Rasheed, 2003).

Third, the franchisors may want to capitalize on macro or industry conditions that would merit internalizing the value of the business format rather than share it with new franchisees. For example, they may find it cheaper to open owned stores when interest rates are very low than to invite franchisees, who have to be incented through sufficient profits that must remain once the franchisor takes out royalties from the revenues generated at an outlet (Jensen, 1983).

Thus, despite being the first explanatory theory underlying the practice of franchising 
(Oxenfeldt \& Kelly, 1968-69) and still held very important, resource scarcity thesis still faces some conceptual challenges. Indeed, at least one previous study has pointed out why it fails to explain the practices of large franchisors (Garg, 2005), who by implication, should not be having resource scarcity once their systems become large. Thus, while positive relationship has already been tested and supported in previous research showing franchising leads to growth of retail chains, the purpose of this study is to examine to what extent franchising helps the growth of large systems, which account for a disproportionately high percentage of all chains.

The remaining paper has been organized as follows. First, hypotheses are developed based on existing literature and our interpretation of it in the context of large franchise systems in quick service restaurant indicator in US. Then, those hypotheses are tested by describing the sample and variables and their measurement, and then conducting analysis. After presenting and describing results, the paper closes with discussion.

\section{Literature Review and Hypotheses}

The earliest research on franchising explained that it occurs because an entrepreneur (franchisor) can develop and grow a chain faster than when relying on a wholly owned chain (Caves \& Murphy, 1976; Combs, Micheal, \& Castrogiovanni, 2004; Oxenfeldt \& Kelly, 1968-69). Crucial to the attractiveness of franchising is the access to the brand name capital developed by the franchisor. This importance was underlined by a franchisee who once was with Burger Chef but then converted to Hardee's. Those that did not convert but decided to operate independently "... are no longer in business. They underestimated the value of the sign" (Bradach, 1998: 17). Literature in franchising has pointed out that brand identity is one of the most important reasons that new entrepreneurs tap into franchising rather than starting on their own (Peterson \& Dant, 1990). A clear and unique brand identity simplifies choice for customers. This theory has been tested more than once. For example, Michael (1999: 318) concluded from a study exploring the importance of differentiation to franchisees of thirty restaurant chains, that franchises "functioned as an instrument of differentiation" for franchisees relative to independent operations.

But the clear edge provided by franchising has implications for competition for resources among franchisors, because over time, that form of organization would become common. QSRI (quick service restaurant industry) is a prime example, where franchisors have to compete fiercely to attract franchisees (Michael, 2009). Facing competition for prospective franchisees, franchisors must build strong brand reputation to signal their competence (Davies, Lassar, Manolis, Prince \& Winsor, 2011) and the value of their system (Shane, Shankar, \& Aravindakshan., 2006). They have to provide a particular quality level they promised to prospective franchisees, and have to reduce their risk of dissatisfaction with the purchase (Keller \& Lehmann, 2006).

New entrepreneurs (prospective franchisees) are willing to provide a bundled set of resources comprising financial capital, managerial talent, and local knowledge when they are convinced that the franchisor's business innovation is embedded strongly in a differentiated brand (Garg, 2013). But, differentiation goes well beyond the uniqueness of physical product or service 
(MacMillan \& McGrath, 1997), and astute entrepreneurs (franchisors) recognize that. They pay attention to many other aspects such as system identifiers (e.g., system name, logo, décor of a retail outlet, etc.) and system facilitators (e.g., POS (point of sales) equipment) that can be sources of differentiation (Kaufmann \& Eroglu, 1999) - - they all affect the value perceived by customers (Garg, 2013). Insights such as these enable them to attract more and better franchisees, particularly in new markets, who then contribute to making the chain larger than other chains that lack capabilities to build a differentiated brand identity. Studies of failure and growth in franchising systems have shown that as much as $75 \%$ chains fail to survive even after 10 years, despite franchising for 7 years on average (Shane, 1996). Thus, franchising-growth relationship acquires special significance, such that large franchising systems keep growing at the same time that small franchising systems might fail. Therefore:

\section{Hypothesis 1: In large Chains, Emphasis on Franchising is Positively Associated with Chain} Size.

Some researchers have argued that as a chain grows, the franchisor faces less scarcity of resources and their brand gains recognition. These factors might prompt the franchisor to raise capital in public markets, as did McDonald's and Burger King followed (McLamore, 1998; Kroc \& Anderson, 1997). At the same time, the franchisor has to face increased agency problems due to spatial dispersion of the chain (Combs \& Ketchen, 2003; Bercovitz, 2004). Monitoring costs and the risk of incompetent partners will keep rising for those franchisors that try to become larger by relying on franchising even when resource scarcity has abated. In turn, they should reduce the dependence on franchising prospective franchisees. At the first glance, these arguments appear compelling. On closer examination, however, it can be argued that increasing risks may not deter aggressive franchisors' quest to grow, and therefor they may continue to exploit their brand reputation even further by opening new franchised outlets.

First, rapid and wide expansion of a chain adds to brand recognition and reputation in unsaturated consumer markets and in turn, prospective franchisees would find the chain still attractive to join. Second, even where the franchisor may have penetrated a market very well, she may not want significant holes in geographic coverage lest competitors fill them. In other words, cannibalization of sales by another outlet of the same brand may be more acceptable than losing the sale to a competitor. Third, reputation can still be extended to new markets using additional expenditures on national advertising or social media. Higher expenditures in promotion may also lead to higher spillover benefits, such as creating latent demand in future markets not targeted at the time. Thus, due to many reasons, a large chain grows to even larger size over time due to franchising.

\section{Hypothesis 2: Positive Effects of Franchising Emphasis on Large Chains Persist Over Time}

Many cost advantages accrue simultaneously to a differentiated chain that becomes larger than rivals (Garg, 2013). Important among these are: economies of scale, greater efficiency of investments in standardization, higher bargaining power over suppliers, etc. Once it is clear that there are accelerating gains to size from franchising, franchisors start paying more attention to agency problems, which has been considered as a limitation to growth of a firm 
for a long time (Jensen \& Meckling, 1976). To achieve better monitoring in a geographically dispersed chain, they invest in innovative technologies such as detailed information systems that collect information from individual outlets at close frequency (Dant \& Nasr, 1998). They also allocate territories to franchisees that show the evidence of adequate monitoring capabilities, there by incorporating multi-unit sub chains within a large chain (Bradach, 1998; Garg et al., 2005). Due to economies of scale, there are higher returns to investments in technology for monitoring in distant markets to mega chains compared to chains that are not as large. These advantages accelerate as more franchisees join a mega system, in turn, further driving up its size.

In summary, incisive large franchisors realize that even when agency problems are increasing, the benefits of franchising do not seize to exist on the net. Therefore, they do not diminish their franchising strategy. This leads to the third and final hypothesis of this paper:

\section{Hypothesis 3: Franchisors of Large Chains do not Reduce Franchising Emphasis Over Time}

The above three hypotheses together form a theory of how franchising continues to help large chains despite their having overcome resource scarcity and having to face increasing threat from agency problems.

\section{Methods}

\subsection{Sample}

Harrigan (1983) has emphasized that researchers should choose methods that are appropriate to a theory. The first important decision in this regard is the choice of sample. Accordingly, the above hypotheses were tested in a sample of restaurant industry because franchising chains emerged in that industry in the fifties (Croc and Anderson, 1977). Already by 1976, it had the first retail chain that achieved $\$ 1$ billion in revenues (1977: 3). Today, this industry has most of the mega chains. Thus, it is very appropriate to test a theory of the effects of franchising strategy on large chains. The sample was drawn from Quick Service Restaurant magazine, which has been publishing a list of the top 50 restaurant chains (by revenue) for many years and thus, allowed an examination of longitudinal data of interest. The latest year for which the data was available is 2017 , and the first time the source reported data in a suitable format and provided the necessary fields was 2012. Table 1 describes key statistics of variables of interest for all of the top 50 restaurant chains from 2012 to 2017.

Table 1. Descriptive statistics and Bivariate Correlations ${ }^{\mathrm{a}}$

\begin{tabular}{|c|c|c|c|c|c|c|c|c|}
\hline Variable & Mean & S. D. & 1 & 2 & 3 & 4 & 5 & 6 \\
\hline 1. Total units in $2013^{a}$ & 3196 & 4591 & - & & & & & \\
\hline 2. Total units in $2017^{\mathbf{b}}$ & 3392 & 4768 & $99^{* *}$ & - & & & & \\
\hline 3. Franchisor owned units in $2013^{a}$ & 532 & 1078 & .29 & $.34^{*}$ & - & & & \\
\hline 4. Franchisor owned units in $2017^{\mathbf{b}}$ & 519 & 1239 & .23 & .29 & $.98^{* *}$ & - & & \\
\hline 5. Ratio of franchised to franchisor owned units $2012^{b}$ & 608 & 3762 & $.76^{* *}$ & $.71^{* *}$ & -.08 & -.07 & - & \\
\hline 6. Ratio of franchised to franchisor owned units $2016^{\mathbf{a}}$ & 935 & 4216 & $.77^{* *}$ & $.76^{* *}$ & -.11 & -.10 & $.95^{* *}$ & - \\
\hline
\end{tabular}




\subsection{Procedures}

Linear regression analysis is the technique that was used for this study, since the interest is in predicting the effect of one variable on another and both the independent and the dependent variables are measured on a scale of continuous nature. Regression procedures suggested and demonstrated by M.S. Lewis-Beck and C. Lewis-Beck (2015) and Hair, Anderson, Tatham and Black (1998) were followed.

To test the first hypothesis, the total number of units a chain had in 2013 (dependent variable) was regressed on the ratio of franchised to franchisor owned units in 2012 (independent variable). Using the independent variable from a previous year is crucial to infer its effect on the dependent variable. The test for the second hypothesis required even further separation between the independent and the dependent variables in time, and the use of Quick Service Restaurant magazine top 50 data allowed to test the effect of 2012 ratio of the number of units franchised to the number of units owned by the franchisor on the total number of units in the chain in 2017. Finally, the third hypothesis was tested. For this, the total number of units a chain had in 2017 was regressed on its ratio of the number of units franchised to the number of units owned by the franchisor in 2016, so that the franchising strategy-chain size relationship could be examined in the most recent year. But before running the regression, the correlation between the 2012 and the 2016 ratios of franchised to franchisor owned units was examined. A high correlation would serve two purposes. First, it would establish continuity of the emphasis on franchising. Second, it will indicate that due to multicollinearity, only one or the other ratio should be used in the regression at a time (Hair, et al., 1998). The ratio having higher correlation with the dependent variable should be used. On the other hand, a low correlation between the two ratios would suggest that the 2012 ratio should be used to control for any substantial change in the emphasis on franchising over time that could affect the tested relationship.

A temptation of including many control variables was avoided. This is because the purpose of this study was to test a particular relationship rather than building an elaborate explanatory model. However, to demonstrate that resource scarcity thesis should not be considered to be a valid explanation for why large chains become larger, it was necessary to control for the number of franchisor owned units in the year in which dependent variable was measured.

\section{Results}

Based on the results shown in Table 2, the following explanation is provided. As predicted in Hypothesis 1, it was found that in large chains, emphasis on franchising is positively associated with chain size. The regression coefficient for the ratio of franchised to franchisor owned units in 2012 was positive and highly significant $(p<0.001)$. Since the regression coefficient for the same (2012) ratio was again positive and highly significant $(p<0.001)$, evidence was found that the positive effects of franchising emphasis on large chains persisted in 2017. Thus, Hypothesis 2 was supported. For testing Hypothesis 3, the correlation between the 2012 and the 2016 ratios of franchised to franchisor owned units was first examined. Because this correlation was very high $(0.95, p<0.001)$, clear evidence for the continuity of the emphasis on franchising by large chains was found. Lastly therefore, a regression was run 
but in order to avoid multicollinearity, the 2016 ratio was only used since it had higher correlation with the dependent variable (0.76) than had the 2012 ratio $(0.71)$.

It is clear from the above explanation that strong results were obtained in terms of both the size of effects and significance of the variable of interest. Variance between 0.6 to 0.7 was explained by a combination of just the one independent variable and $a$ control variable. This strength occurred in a relatively small, but very appropriate sample that was aligned with the theory (Harrigan, 1983) for large chains that this study attended. Thus, unlike studies that included a lot of variables for prediction and used very large samples (for example, Brandes, Dharwadkar, \& Suh SMJ 2016 had a sample of 7000 and used 16 variables) and yet obtained very low variance per variable (0.02 in that example), this study was both very effective and efficient.

Table 2. Parameter Estimates for the Linear Regression Models

\begin{tabular}{|c|c|c|c|}
\hline & $\begin{array}{l}\text { Model } 1 \text { Prediction of } \\
\text { Total Units in } 2013 \\
(\mathrm{~N}=45)\end{array}$ & $\begin{array}{l}\text { Model } 2 \text { Prediction of } \\
\text { Total Units in } 2017 \\
\qquad(\mathrm{~N}=47)\end{array}$ & $\begin{array}{l}\text { Model } 3 \text { Prediction of } \\
\text { Total Units in } 2017 \\
(\mathrm{~N}=45)\end{array}$ \\
\hline Variable & Reg. Coeff. ${ }^{\mathrm{a}}$ & Reg. Coeff. ${ }^{\mathrm{a}}$ & Reg. Coeff. ${ }^{a}$ \\
\hline $\begin{array}{l}\text { Ratio of franchised to } \\
\text { franchisor owned units } 2012\end{array}$ & $0.79^{* * *}$ & $0.73^{* * *}$ & \\
\hline Franchisor owned units in 2013 & $0.36^{* * * *}$ & & \\
\hline $\begin{array}{l}\text { Ratio of franchised to } \\
\text { franchisor owned units } 2016\end{array}$ & & & $0.8^{* * *}$ \\
\hline Franchisor owned units in 2017 & & $0.34^{* * *}$ & $0.36^{* * * *}$ \\
\hline Adjusted $\mathrm{R}^{2}$ & 0.69 & 0.60 & 0.71 \\
\hline Overall F & $49.2^{* * *}$ & $35.4^{* * * *}$ & $51.0^{* * * *}$ \\
\hline Change in $\mathrm{R}^{2}$ & 0.70 & 0.61 & 0.70 \\
\hline Change in F & $49.2^{* * *}$ & $35.4^{* * *}$ & $51.0^{* * *}$ \\
\hline
\end{tabular}

${ }^{a}$ Standardized Regression Coefficients are presented

**** $\mathrm{p}<0.001$

${ }^{* *} \mathrm{p}<0.01$

\section{Discussion}

With so much proliferation of franchising all over the world, research must pay significant attention to why large chains continue to franchise. Previous research in franchising suggests that such chains should no more be facing scarcities of resources, so should not emphasize franchising when they add units. In addition, they must have experienced the problems agents bring that would compromise quality offered by the franchisor (Michael, 2000), so from a monitoring point of view as well, the emphasize on franchising should not be expected to remain. This article developed theoretical arguments as to why even large chains should continue to emphasize franchising relative to franchisor owned outlets and then empirically examined if they indeed do so.

Only franchisors that have overcome resource scarcity can afford to expand mainly through 
their own investments. Compelling evidence was found in this study that even they don't rely on their own capacity to expand. Instead, they continue to emphasize franchising as the primary means of growth. Why is that the case, despite the increasing risk of diluted quality of their differentiated total offer as more franchisees are encouraged to participate in exploiting the success of their brand? It is because new franchisees will bring more resources that will allow the chain to compete better with its main rivals. They are convinced franchising will continue to drive growth and see threat to quality as an acceptable consequence of the quest to continue becoming larger.

\section{Implications and Limitations}

This study makes contributions to theory, practice, and methods. Although research on examining the question "why retail firms franchise" has spawned many studies over five decades, theoretical advancement is still incomplete. But in addition to finding a new theory to answer this important question, examining boundary conditions is perhaps more important. A sharp focus of research on this question from primarily a relevance point of view will aid practitioners more clearly. Therefore, only large chains were examined to see how relevant emphasis on franchising is for them, because previous explanations of franchising have raised a question mark on the need for - and efficacy of - franchising once a chain becomes large. Those explanations argue that a large chain should be able to reinvest their profits. So why take the risk of newcomer franchisees acting opportunistically, in turn causing resentment among the early franchisees and simultaneously, hurting the brand image? Results of this study suggest those are the risks large franchisors are willing to take and therefore, they continue emphasis on franchising. This is a very useful finding for those large franchisors who are considering adding units by investing in their own units. They should realize that their strategy will likely result in a competitor becoming larger, thus getting higher scale advantage, and achieving deeper penetration sooner.

The theory and results of this paper have substantial implications for entrepreneurs looking to invest in a very popular franchise as well. They must anticipate that franchisors of large chains keep adding outlets, and mostly through franchising. Thus, cannibalization of sales from the outlet(s) he owns will be likely. While he may lose profits, the franchisor will not, because the lost royalty on diminished revenue from his outlet(s) will be offset by royalty earned from a new outlet. Several safeguards should be explored, such as scouting for franchisors that grant territorial rights, taking the franchise of a brand that has not saturated their market, researching distance between outlets of different brands, etc.

Quick service restaurant industry was selected to test theory, for two reasons. First, that industry uniquely shows a majority of large to mega chains. Second, consumers of that industry are likely to be less quality sensitive, since they are more concerned about savings, speed and convenient locations (Garg et al., 2013). The larger a chain, the greater its ability to build competitive advantage on those key success factors. Future researchers are encouraged to likewise examine other contexts, such as differences in industries and countries. The advantage of size may not be as relevant to some industries such as interior decoration; more relevant advantage there may be the ability to customize based on skills and creativity of the 
person providing solutions and their implementation. The requirement for these abilities might make it difficult to find many capable franchisees, who are also financially sound, in a given city. Thus, franchisors may have to reduce their emphasis on franchising in such industries. Other reasons to expect limitations on franchising in different industries may be theoretically hypothesized and tested in a cross-industry sample.

The sample size of 47 is not large by any means and may appear to be a limitation at the first glance. However, since it is drawn from only one industry, less variations across firms is a reasonable expectation compared to a multi-industry large sample. Therefore, previous research of franchising has, at times, used even smaller samples. For example, Michael (2000) studied the influence of franchising on quality in 35 restaurant chains. Thus, the sample size should be considered sufficient for this study, especially when no firms are small. Although restaurant industry has been modal for franchising (Dant \& Nasr, 1998), it is still one industry. Therefore, caution is still needed when generalizing findings of this study to other industries.

The use of archival, secondary data may raise the issues of validity of measures. However, since the study didn't use any proxies or impute any perceptual meanings to hard data, the nature of data should not be considered a limitation. Indeed, this study has avoided limitations typically associated with perceptual measures, such as social desirability and memory recall. Such limitations can be severe in a longitudinal design, which was the nature of the data used in this study.

This paper concludes with a call for conservation of research resources. Very likely, increasingly large production of research occurs due to a growing supply of researchers each of whom must compete hard for publishing. But, a consideration for the consumption of resources for research, such as monetary budgets and respondents' time (in survey research), is important. Information overload for readers such abundance in research generates also deserves consideration. Believing strongly in these research values, I tested the effect of only one predictor variable grounded in a strong theory which goes back to 50 years. Still, it has not been tested under certain boundary conditions. Only one control variable was used, whose importance is derived from the relevant literature. Yet, large effect size and very high significance were found in a sample carefully chosen for the theory at hand. It is hoped that the simplicity of this research should also increase its readability, especially for those who lack background in advanced research methods, statistical analyses, and above all, time. Clearly, most entrepreneurs face all those constraints, whether they are franchisors or franchisees. Therefore, for research to be of relevance to practitioners, it needs to be of high significance to them and easy to read. The current paper meets those two important criteria of practical usefulness.

\section{References}

Akremi, A. E., Mignonac, K., \& Perrigot, R. (2010). Opportunistic behaviors in franchise chains: The role of cohesion among franchisees. Strategic Management Journal, 32(9), 930-948. https://doi.org/10.1002/smj.912

Bercovitz, J. E. (2004). The Organizational Choice Decision in Business Format Franchising: 
An Empirical Test. Contributions to Management Science Economics and Management of Franchising Networks, 38-65. https://doi.org/10.1007/978-3-7908-2662-3_3

Bradach, J. L. (1998). Franchise Organizations. Boston, MA: Harvard Business School Press.

Brandes, P., Dharwadkar, R., \& Suh, S. (2015). I know something you dont know!: The role of linking pin directors in monitoring and incentive alignment. Strategic Management Journal, 37(5), 964-981. https://doi.org/10.1002/smj.2353

Caves, R. E., \& Murphy, W. F. (1976). Franchising: Firms, Markets, and Intangible Assets. Southern Economic Journal, 42(4), 572. https://doi.org/10.2307/1056250

Cochet, O., \& Garg, V. K. (2008). How Do Franchise Contracts Evolve? A Study of Three German SMEs*. Journal of Small Business Management, 46(1), 134-151.

https://doi.org/10.1111/j.1540-627X.2007.00236.x

Combs, J. G., \& Ketchen, D. J. (2003). Why Do Firms Use Franchising as an Entrepreneurial Strategy?: A Meta-Analysis. Journal of Management, 29(3), 443-465.

https://doi.org/10.1016/S0149-2063_03_00019-9

Combs, J. G., Michael, S. C., \& Castrogiovanni, G. J. (2004). Franchising: A Review and Avenues to Greater Theoretical Diversity. Journal of Management, 30(6), 907-931. https://doi.org/10.1016/j.jm.2004.06.006

Dant, R. P., \& Nasr, N. I. (1998). Control techniques and upward flow of information in franchising in distant markets: Conceptualization and preliminary evidence. Journal of Business Venturing, 13(1), 3-28. https://doi.org/10.1016/S0883-9026(97)00040-2

Davies, M. A., Lassar, W., Manolis, C., Prince, M., \& Winsor, R. D. (2011). A model of trust and compliance in franchise relationships. Journal of Business Venturing, 26(3), 321-340. https://doi.org/10.1016/j.jbusvent.2009.09.005

Eisenhardt, K. (1988). Agency-and Institutional-Theory Explanations: The Case of Retail Sales Compensation. Academy of Management Journal, 31(3), 488-511.

https://doi.org/10.5465/256457

Eisenhardt, K. M. (1989). Agency Theory: An Assessment and Review. The Academy of Management Review, 14(1), 57-74. https://doi.org/10.2307/258191

Fama, E., \& Jensen, M. (1983). Separation of Ownership and Control. The Journal of Law Economics, 26(2), 301-325. https://doi.org/10.1086/467037

Gallini, N., \& Lutz, N. (1992). Dual Distribution and Royalty Fees in Franchising. Journal of Law, Economics, \& Organization, 8(3), 471-501.

Garg, V. K., \& Rasheed, A. A. (2003). International multi-unit franchising: An agency theoretic explanation. International Business Review, 12(3), 329-348.

https://doi.org/10.1016/S0969-5931(03)00019-2 


\section{Macrothink}

Business and Economic Research ISSN 2162-4860 2019, Vol. 9, No. 1

Garg, V. K. (2005). Conceptualizing industry variations in the survival of franchising systems, Journal of Business \& Entrepreneurship, 17(1), 14-27.

Garg, V. K., Rasheed, A. A., \& Priem, R. L. (2005). Explaining franchisors' choices of organization forms within franchise systems. Strategic Organization, 3(2), 185-217. https://doi.org/10.1177/1476127005052210

Garg, V. K. (2013). Does Multi-unit Franchising Aid Differentiation? An Exposition. The Journal of Applied Management and Entrepreneurship, 18(1), 3-26.

https://doi.org/10.9774/GLEAF.3709.2013.ja.00003

Garg, V. K., Priem, R. L., \& Rasheed, A. A. (2013). A Theoretical Explanation of the Cost Advantages of Multi-unit Franchising. Journal of Marketing Channels, 20(1-2), 52-72. https://doi.org/10.1080/1046669X.2013.747859

Hair, J. F., Anderson R. E., Tatham R. L., \& Black, W. C. (1998). Multivariate Analysis. New Jersey: Prentice Hall.

Harrigan, K. R. (1983). Research Methodologies for Contingency Approaches to Business Strategy. The Academy of Management Review, 8(3), 398. https://doi.org/10.2307/257828

Jensen, M. (1983). Organization theory and methodology. Accounting Review, 50, 319-339.

Jensen, M., \& Meckling, W. (1976). Theory of the Firm: Managerial Behavior, Agency Costs, and Ownership Structure. Journal of Financial Economics, 3, 305-60.

https://doi.org/10.1016/0304-405X(76)90026-X

Kaufmann, P. J., \& Eroglu, S. (1999). Standardization and adaptation in business format franchising. Journal of Business Venturing, 14(1), 69-85.

https://doi.org/10.1016/S0883-9026(97)00097-9

Keller, K. L., \& Lehmann, D. R. (2006). Brands and Branding: Research Findings and Future Priorities. Marketing Science, 25(6), 740-759. https://doi.org/10.1287/mksc.1050.0153

Kroc, R., \& Anderson, R. (1977). Grinding it out: The making of McDonalds. New York, NY: St. Martins Griffin.

Lewis-Beck, M. S., \& Lewis-Beck, C. (2016). Applied regression: An introduction. Thousand Oaks, CA: Sage. https://doi.org/10.4135/9781483396774

MacMillan, I. C. \& McGrath, R. G. (1997). Discovering new points of differentiation, Harvard Business Review, 75(July-August), 133-145.

McLamore, J. W. (1998). The Burger King: Jim McLamore and the building of an empire. New York, NY: McGraw-Hill.

Michael, S. (1999). The Elasticity of Franchising. Small Business Economics, 12(4), 313-320. https://doi.org/10.1023/A:1008019418231

Michael, S. C. (2000). The effect of organizational form on quality: The case of franchising Journal of Economic Behavior, 43(3), 295-318. 
https://doi.org/10.1016/S0167-2681(00)00125-6

Michael, S. C. (2003). First mover advantage through franchising. Journal of Business Venturing, 18(1), 61-80. https://doi.org/10.1016/S0883-9026(01)00085-4

Michael, S. C. (2009). Entrepreneurial signaling to attract resources: The case of franchising. Managerial and Decision Economics, 30, 405-422.

https://doi.org/10.1002/mde.1460

Oxenfeldt, A. R., \& Kelly, A. O. (1968-69). Will successful franchise systems ultimately become wholly-owned chains?. Journal of Retailing, 44(4), 69-83.

Perman, S. (2010). In-N-Out Burger: A behind-the-counter look at the fast-food chain that breaksall the rules. New York, NY: Harper Collins Publishers.

Peterson, A., \& Dant, R. P. (1990). Perceived advantages of the franchise option from the franchisee perspective: Empirical insights from a service franchise. Journal of Small Business Management, 28, 46-61.

Shane, S. A. (1996). Hybrid Organizational Arrangements and Their Implications for Firm Growth and Survival: A Study of New Franchisors. Academy of Management Journal, 39(1), 216-234. https://doi.org/10.5465/256637

Shane, S., Shankar, V., \& Aravindakshan, A. (2006). The Effects of New Franchisor Partnering Strategies on Franchise System Size. Management Science, 52(5), 773-787. https://doi.org/10.1287/mnsc.1050.0449

Thomas, R. D. (1992). Dave's Way. New York, NY: The Berkley Publishing Group.

Wu, C-W. (2015), Antecedents of franchise strategy and performance, Journal of Business Strategy, 68(7), 1581-1588. https://doi.org/10.1016/j.jbusres.2015.01.055

\section{Copyright Disclaimer}

Copyright for this article is retained by the author(s), with first publication rights granted to the journal.

This is an open-access article distributed under the terms and conditions of the Creative Commons Attribution license (http://creativecommons.org/licenses/by/3.0/). 